Florida A\&M University College of Law

Scholarly Commons @ FAMU Law

2010

Domesticating International Law Through Truth and Reconciliation Commissions: The Case of the Liberian TRC

Jeremy I. Levitt

Follow this and additional works at: https://commons.law.famu.edu/faculty-research

Part of the International Humanitarian Law Commons, and the International Law Commons 


\title{
CONCLUSION
}

The South African Constitutional Court's pioneering incorporation and interpretation of international and foreign legal authorities has generated an expansive human rights jurisprudence that should serve to inspire the international community. Whether the Court's commitment to an inclusive interpretive mode will continue remains to be seen. What is certain is that the implementation of rights won before the Court will continue to depend on the sustained commitment of civil society to remain engaged in challenging rights violations in the judiciaries of Africa and beyond.

\section{Domesticating International LaW Through Truth and Reconciliation Commissions: The Case of the Liberian TRC}

\author{
By Jeremy I. Levitt ${ }^{*}$
}

\section{INTRODUCTION}

On March 16, 2010, Professor Angela Banks invited me to participate in a panel discussion entitled, The Rising Use of International Law by African Judiciaries, which would took place on March 26th at the 104th Annual Meeting of the American Society of International Law (ASIL) in Washington, DC. I was pleased to receive the invitation and honored to join the esteemed panel that included Professors Erika George and Obiora Okafor. Professor Banks' timely envisioning of the topic provided me with a wonderful opportunity to discuss my work as head of International Technical Advisory Committee (ITAC) of the Truth and Reconciliation Commission of Liberia (Liberian TRC).

After agreeing to participate on the panel, I immediately asked myself: What do we mean by African judiciary? For a continent comprised of fifty-three countries with different histories, legal systems, and traditions, is it useful to begin my inquiry with mono-geographical lenses? Is there such a thing as the African judiciary? Over the years, I have worked with several African judiciaries and learned early that there is no agreed-upon definition of judiciary or what specific institutions within a state comprise it. For example, do African traditional authority structures and African customary law form a part of the African "judiciary'? Do truth and reconciliation commissions, particularly those empowered to make quasi-judicial and binding determinations, decisions, and recommendations, form a part of the judicial system? These questions lead to a series of others, including: What structures constitute the judiciary in Africa? How, if at all, does the African judiciary differ from those in other countries?

While there is a growing literature on judicial independence, judicial review, and judicial powers in Africa, few have defined what constitutes the "African judiciary." For purposes of my remarks, I broadly define it to mean a system of courts, tribunals, or other administratively designated judicatures that interpret and apply law in the name of the sovereign or state. The Statute of the African Charter on Human and Peoples Rights (ACHPR), Africa's foremost human rights treaty, does not specifically use the term "judiciary"; rather, it makes broad reference to courts, tribunals, or other adjudicatory mechanisms. What is abundantly clear, however, is that African courts, whether general or specific, contemplate international law as do African policy-makers in making legislation and policy.

${ }^{*}$ Associate Dean for International Programs, Distinguished Professor of International Law, and Director of the Center for International Law and Justice (CILJ), Florida A\&M University College of Law. 
African states actively domesticate international law through judicial capacity-building in, for example, Botswana's Industrial Court's use of the Convention for Elimination of All Forms of Discrimination Against Women (CEDAW) and International Labor Organization conventions in the Moatswi v. Fencing Center case; Chief Justice of the Supreme Court of Ghana's creation of the Human Rights Division of the Ghana High Court; and the institution of a sexual crimes division-Liberia's Court ' $E$ '”-by the Liberian legislature. Moreover, high courts in Africa have demonstrated their willingness to adjudicate cases using regional and international law. For instance, in Kaunda v. President of the Republic of South Africa, the case turned on whether South African mercenaries who had been captured in Zimbabwe and threatened with prosecution and capital punishment after an unfair trial in a third state could claim diplomatic protection from South Africa, i.e., could claim a right to be extradited back to South Africa. In 1990 Benin's Constitutional Court determined that the ACHPR was an "interpretive tool" for the constitution, including its "freedom to associate"'-related provision. In 2001 the Botswana High Court in Unity Dow employed international human rights law to challenge the constitutionality of its 1982 Citizenship Act, and in the 2000 Windhoek Prison case, the Namibian Supreme Court used the International Convention on Civil and Political Rights (ICCPR) and the Convention Against Torture (CAT) to determine that chains or mechanical restraints violated a person's right to dignity, and his or her right not to be tortured or subjected to degrading and inhumane treatment.

While these courts and cases provide only a brief snapshot of the various ways in which international law has been and is being used by African judiciaries, it is important to note that this phenomenon is not exceptional.

While few know about the impact of international law on domestic courts, much less is known about the normative force that truth and reconciliation commissions have played in fashioning and domesticating international rules. Hence the forgoing analysis will focus on the various and distinct ways in which the Liberian TRC not only applied and domesticated international law, but also how it made a normative contribution to the practice of truth commissions and transitional justice, namely the human rights protective regime. Before I embark in this intellectual exercise, however, it is important briefly to highlight the mission and mandate of the ITAC and TRC, as well as their use of international law to fulfill their mandate as quasi-judicial mechanisms.

\section{International Technical Advisory Committee}

The Act to Establish the Truth and Reconciliation Commission of Liberia (TRC Act) arose from the Comprehensive Peace Agreement (CPA) (between the Liberian government and the various warring factions) of August 18, 2003, and was enacted by the National Transitional Legislative Assembly of the National Transitional Government of Liberia of June 10, 2005. The CPA and TRC Acts are the products of nearly fourteen years of intermittent highintensity armed conflict that resulted in over 250,000 deaths and the literal destruction of Liberia's political, economic, and social infrastructure. Few populations in history have experienced the carnage and abandonment that besieged and entrapped Liberia.

During my tenure, the Liberian TRC was composed of eight commissioners, one ITAC advisor, an executive secretary and secretariat, special magistrate, investigative unit, dozens of support staff, and numerous international partners.

In 2008 the UN High Commissioner for Human Rights (UNHCHR) nominated me to be a member of ITAC, and I was later formally appointed to the position by Liberian President Ellen Johnson-Sirleaf, the first democratically elected female president in Africa. The ITAC 
was supposed to be composed of two persons nominated by the Economic Community of West African States (ECOWAS) and one person designated by the UNHCHR. According to the TRC Act, ITAC advisors were to be persons of "international distinction and repute." After the TRC went through three ECOWAS-nominated ITAC advisors within a very short period of time, I was selected by the UNHCHR to "fill in the gap."

Pursuant to the TRC Act, ITAC advisors functioned as non-voting members of the TRC. We had full disclosure rights in all matters and possessed the same duties and responsibilities as commissioners. ITAC advisors were entitled to attend all meetings and forums of the commission, provide advisory opinions on any issues relevant to its work, and enjoy the full rights and privileges as commissioners. As the head of ITAC, I operated in precarious legal and political realms where lines of authority and legitimacy were often blurred. As the UNHCHR and government of Liberia nominee and appointee, respectively, mandated under domestic law, to advise on all aspects of the TRC's mandate, I found my plate to be more than full. The ITAC position was emblematic of a growing tendency of post-conflict states toward the adoption of shared-sovereignty arrangements in the development of transitional peace and justice mechanisms. I was essentially a foreigner serving in an official capacity in the Liberian government (with the full diplomatic privileges and immunities of a diplomatic representative), compensated by the United Nations.

\section{MANDATE}

After reviewing the TRC Act and corollary materials, I immediately determined that my principal clients were, first, the people of the Liberia, and second, the Liberian TRC. Early in the process, I urged the commission to resolve formally that it was a quasi-judicial body with the power, among other things, to determine those most responsible for committing gross human rights violations (GHRV), serious violations of humanitarian law (SHLV), egregious domestic crimes (EDC), and economic crimes against Liberians and Liberia, and to make binding recommendations to the government with which it would have a positive duty to implement.

In order to carry out the commission's mandate, I worked with the commission to domesticate and mainstream international human rights, criminal law, humanitarian law, doctrine, and jurisprudence into its work. The temporal mandate of the TRC spanned from January 1979 to October 2003. In short, the central aim of the Liberian TRC was to promote national peace, security, unity, and reconciliation by:

(1) investigating GHRV, SHLV, crimes against humanity, and economic crimes;

(2) determining the root causes of disorder and violent conflict;

(3) determining those responsible for committing GHRV, SHLV, and EDC;

(4) determining the impact of armed conflict on victims;

(5) providing a forum to address impunity, and for victims and perpetrators to share their experiences;

(6) conducting a critical review of Liberia's historical past to recognize truths and dispel falsehoods about its socioeconomic and political development;

(7) adopting specific mechanisms and procedures to address the experiences and needs of women, children, and vulnerable groups, paying particular attention to genderbased violations, child soldiers, and recommending measures to rehabilitate victims of human rights violations;

(8) preparing a comprehensive report; and

(9) making binding recommendations to the President. 
Since the TRC Act and mandate were, in certain respects, ambiguous, silent, or ill-defined, I spent considerable time working with the commission to determine what bodies of law were applicable to whom, where, and when, given the TRC's complex temporal and spatial authority. This entailed developing a coherent legal framework to underwrite its mandate, including the introduction of civil sanctions and penal crimes. As a body of law, the TRC Act was itself unique and trend-setting. Unlike most TRCs that are preoccupied with truth and reconciliation, accountability and justice based on controlling regional and international law conceptions of justice were vital to the work of the Liberian TRC. Similarly, the blunt rejection of impunity through amnesty, restoring the human dignity of victims, determining and holding accountable those most responsible for committing GHRV, SHLV, EDC, and economic crimes, and gender mainstreaming in all TRC operations were equally important features of its work.

Consequently, the Liberian TRC made several outstanding contributions to the law and doctrine of truth commissions, as well as to contemporary notions of transitional justice. As previously noted, it not only made individual determinations on those responsible for committing GHRV, SHLV, and EDC, but it also made group-based determinations that held nearly every warring faction and its leaders, financiers, and combatants responsible for such crimes. In addition, the Liberian TRC recommended and provided the structural template for the establishment of an Extraordinary Criminal Court for Liberia - an internationalized domestic criminal court - to prosecute several dozen of the worst violators, and also recommended that hundreds of high violators, especially serial killers and sexual abusers, be prosecuted in Liberia's criminal courts " $A$ " and "E.",

While the TRC was precluded from providing amnesty, it explicitly held child soldiers harmless for any crimes and did not recommend prosecution for a small number of combatants who testified willingly and truthfully — an approach that fell short of a formal amnesty. It also redefined economic crimes to suit the West African socioeconomic landscape and applied them to several persons and companies responsible for committing such crimes. Perhaps the most innovative recommendation called for the establishment of national Palava Hut processes - traditional dispute resolution and reconciliation mechanisms similar to the gacaca court system in Rwanda-for all victims and perpetrators of Liberia's various episodes of conflict. Lastly, in an attempt to curb and expose corruption, the commission explicitly exposed two commissioners for engaging in corrupt and obstructive behavior. While Liberia continues to teeter on the dangerous lines of conflict and democracy, and remains largely reliant on a waning United Nations peace-keeping force once as large as fifteen thousand people, the TRC, amid rapid corruption and threats of bodily peril, boldly domesticated international human rights, humanitarian law, and criminal law standards into its work with the hope that the Liberian government will implement its binding recommendations for the greater good of peace, justice, and reconciliation. 